\title{
HUBUNGAN ANTARA PANTANG MAKANAN DENGAN PENYEMBUHAN LUKA PERINEUM DI RUANG MAWAR RSI JEMURSARI SURABAYA
}

\author{
Rentika Fitri Marcelina \\ (Universitas Nahdlatul Ulama Surabaya, FKK, Prodi D III Kebidanan) \\ Fauziyatun Nisa \\ (Universitas Nahdlatul Ulama Surabaya, FKK, Prodi D III Kebidanan, \\ Email: fauziyatun.nisa@unusa.ac.id)
}

\begin{abstract}
Penyembuhan luka perineum dipengaruhi oleh beberapa faktor salah satunya yaitu pantang makanan. Dalam hal ini masih ada ibu nifas yang melakukan pantang makanan yang salah. Sehingga tidak jarang ibu mengalami gangguan dalam penyembuhan luka perineumnya. Penelitian ini bertujuan untuk mengetahui hubungan antara pantang makanan dengan penyembuhan luka perineum di Ruang Mawar RSI Jemursari. Jenis penelitian ini adalah analitik observasional dengan rancangan cross sectional. Populasinya seluruh ibu yang partus di RSI Jemursari Surabaya sebesar 42 orang. Sampel sebesar 38 responden diambil dengan teknik Simple random sampling. Variabel Independent Pantang makanan dan variabel dependent penyembuhan luka perineum. Pengumpulan data menggunakan kuesioner. Data dianalisa menggunakan uji Mann Whitney dengan tingkat kemaknaan $\alpha=0,05$. Hasil penelitian menunjukan bahwa hampir seluruh $(76 \%)$ ibu nifas yang tidak berpantang makanan hampir seluruhnya (82\%) penyembuhan lukanya baik. Hasil uji statistic didapatkan $\rho=0,000<\alpha=0,05$, maka $\mathrm{H}_{0}$ artinya ada hubungan antara pantang makanan dengan penyembuhan luka perineum di RSI Jemursari. Dari penelitian ini disimpulkan bahwa semakin ibu berpantang makanan yang dibutuhkan selama masa nifas, maka akan mempengaruhi penyembuhan luka perineum. Saran bagi tenaga kesehatan lebih komprehensif untuk memberikan penjelasan tentang bahaya pantang makanan tidak hanya kepada ibu nifas tetapi juga keluarganya.
\end{abstract}

Kata kunci : penyembuhan luka perineum, pantang makanan, ibu nifas

\section{ABSTRACT}

Perineum wound healing is affected by several factors such as food abstinemce. In this case, there are some puerperal mothers perform the food abstienence wrongly. So, no wonder they have interference in facing perineum wound healing. The aim of this research is find out the relation between food abstinence and perineum wound healling in Ruang Mawar RSI Jemursari. This is an observational analytic reaerch with Cross Sectional research design. The population of the research is all 42 people of parturition mothers in RSI Jemursari Surabaya and the samples are 38 respondens which is collected by Simple Random Technique, the independent varieble of the researchis food abstinence and the dependent variable is perineum wound healling. The data is collected by using questionnaire and analyzed by using Mann Whitney test with the level of significance $\alpha=0,05$. The result of this research shows that almost all 
of the puerperal mothers (82\%) who do not perform the food abstinence have good ability in perineum wound healing. Statistic test result gets $\rho=0,000<$ $\alpha=0,05$, so $H^{\circ}$ mean there is a relation between food wound healing in RSI Jemursari. From this research, that more mother abstain from food which is needed during the postpartum period, then it affect the perineal wound healing, suggestions for a more comprehensive health workers to give explanations about the dangers of abstinence from food not only to the post partum mothers, but also their families.

Keywords: Perineum wound healing, food abstinence, puerperal mother

\section{PENDAHULUAN}

Masa post partum atau nifas adalah masa sesudah persalinan dimulai setelah kelahiran plasenta dan berakhirnya ketika alat-alat kandungan kembali seperti keadaan sebelum hamil, masa nifas berlangsung selama 6 minggu (Saiffudin,2002).

Pada kondisi ini ibu nifas membutuhkan makanan bergizi dan cukup kalori, seperti makanan yang mengandung protein, banyak cairan, sayur-sayuran dan buah-buahan (Mochtar, 2002). Tarak (pantang) terhadap makanan tidak boleh dilakukan oleh ibu post partum karena dapat memperlambat proses penyembuhan luka perineum sedangkan dalam proses penyembuhan luka sangat membutuhkan protein, maka ibu post partum dianjurkan untuk makan dalam pola yang benar sesuai dengan kualitas dan kuantitasnya (Iskandar, 2010).

Penyembuhan luka pada ibu pasca persalinan dipengaruhi oleh berbagai faktor diantaranya faktor eskternal meliputi; lingkungan, pengetahuan, sosial ekonomi, penanganan petugas, kondisi ibu, gizi dan pantang makanan. Sedangkan faktor internal meliputi; usia, penanganan jaringan, hemorogi, hipovelemia, faktor lokal edema, defisit nutrisi, personal hygiene, defisit oksigen, dan over aktifitas (Smetzer, 2002).

Salah satu perilaku yang tidak sehat bagi ibu nifas adalah kebiasaan pantang makanan. Adapun dampak yang ditimbulkan jika ibu nifas melakukan pantang makanan adalah kekurangan zat gizi sehingga penyembuhan luka lebih lama bahkan bisa timbul infeksi. Apalagi makanan bergizi itu sangat dibutuhkan untuk pemulihan kondisi kesehatan, mempercepat penyembuhan luka, involusi alat - alat kandungan dan untuk menunjang proses laktasi, sehingga ibu tidak dianjurkan untuk berpantangan makanan (Subijakto, 2011).

\section{METODE PENELITIAN}

Jenis penelitian yang akan digunakan adalah analitik dengan tujuan untuk mencari hubunganan antara pantang makanan dengan penyembuhan luka perineum di Ruang Mawar RSI Jemursari Surabaya. Berdasarkan waktunya, desain penelitian yang digunakan adalah Cross Sectional, yaitu dimana variabel independen (Ibu Post Partum) dan dependen (Ibu Post Partum yang panang makanan) diobservasi sekaligus pada waktu 
yang sama. Populasi penelitian ini adalah semua ibu yang partus di Ruang Mawar RSI Jemursari Surabaya sebanyak 42 orang. Sampel pada penelitian ini adalah sebagian ibu yang partus di Ruang Mawar RSI Jemursari Surabaya sebesar 38 orang. Dalam penelitian ini pemilihan sampel dilakukan secara probability sampling dengan teknik simple random sampling, dimana semua ibu yang partus di Ruang Mawar RSI Jemursari Surabaya mendapatkan kesempatan yang sama dalam pemilihan responden setelah dilakukan pengundian atau acak.

Dalam analisis data pada penelitian ini menggunakan uji signifikansi yang bertujuan untuk mengetahui keeratan hubungan antara variabel digunakan uji Mann Whitney dan bantuan program SPSS 16.0 for windows dengan tingkat kemaknaan $\alpha$ $=0,05$. Jika $\rho<\alpha$ maka o ditolak yang berarti ada hubungan antara variabel independent dengan variabel dependent.

\section{HASIL}

Karakteristik responden berdasarkan pola pikir ibu menurut Santrock (2011) dibagi menjadi usia <20 tahun (Remaja), usia 21 tahun-35 tahun (Dewasa Muda), dan usia > 35 tahun (Dewasa Madya) dapat dilihat dalam tabel 5.1 dibawah ini :

Tabel 1: Distribusi Frekuensi responden berdasarkan usia ibu di Ruang Mawar RSI Jemursari Surabaya bulan Juni 2015

\begin{tabular}{cccc}
\hline No & Usia ibu & Frekuensi & Presentase $(\%)$ \\
\hline 1 & $<20$ Tahun & 2 & 5 \\
2 & $21-35$ Tahun & 30 & 79 \\
3 & $>35$ Tahun & 6 & 16 \\
\hline & Jumlah & 38 & 100 \\
\hline
\end{tabular}

Berdasarkan tabel 1 menunjukkan bahwa dari 38 responden hampir seluruhnya $(79 \%)$ berumur 21-35 tahun.

Karakteristik responden berdasarkan tingkat pendidikan menurut Undang undang sistem Pendidikan Nasional Nomor 20 tahun 2006 dikelompokkan dalam tingkat dasar (SD, SMP dan sederajat), pendidikan menengah ( SMU dan sederajat) dan pendidikan tinggi ( Diploma, Sarjana) dapat dilihat dari table 5.2 dibawah ini:

Tabel 2: Distribusi frekuensi responden berdasarkan pendidikan ibu di Ruang Mawar RSI Jemursari Surabaya bulan Juni 2015

\begin{tabular}{cccc}
\hline No & Pendidikan & Frekuensi & Presentase (\%) \\
\hline 1 & Dasar & 0 & 0 \\
2 & Menengah & 33 & 87 \\
3 & Tinggi & 5 & 13 \\
\hline & Jumlah & 38 & 100 \\
\hline
\end{tabular}

Berdasarkan tabel 2 menunjukkan bahwa dari 38 responden hampir seluruhnya $(87 \%)$ berpendidikan menengah. 
Untuk mengetahui distribusi frekuensi tentang pantang makanan atau tidak pantang makanan ibu dapat dilihat dari tabel berikut:

Tabel 3: Distribusi Frekuensi responden berdasarkan pantang makanan atau tidak pantang makanan ibu nifas di Ruang Mawar RSI Jemursari Surabaya bulan Juni

\begin{tabular}{cccc}
\hline \multicolumn{3}{c}{2015} \\
\hline & $\begin{array}{c}\text { Pantang } \\
\text { Makanan }\end{array}$ & Frekuensi & Presentase (\%) \\
\hline 1 & $\begin{array}{c}\text { Pantang } \\
\text { Makanan }\end{array}$ & 9 & 24 \\
2 & $\begin{array}{c}\text { Tidak } \\
\text { Pantang } \\
\text { Makanan }\end{array}$ & 29 & 76 \\
& Jumlah & 38 & 100 \\
\hline
\end{tabular}

Berdasarkan tabel 3 menunjukkan bahwa dari 38 responden hampir seluruhnya $(76 \%)$ tidak pantang makanan dan sebagian kecil (24\%) berpantang makanan.

Untuk mengetahui distribusi frekuensi tentang tingkat penyembuhan luka perineum ibu dapat dilihat dari tabel berikut:

Tabel 4: Distribusi Frekuensi responden berdasarkan penyembuhan luka perineum ibu nifas di Ruang Mawar RSI Jemursari Surabaya bulan Juni 2015

\begin{tabular}{cccc}
\hline No & $\begin{array}{c}\text { Penyembuhan } \\
\text { Luka Perineum }\end{array}$ & Frekuensi & $\begin{array}{c}\text { Presentase } \\
(\%)\end{array}$ \\
\hline 1 & Baik & 31 & 82 \\
2 & Sedang & 5 & 13 \\
3 & Buruk & 2 & 5 \\
\hline & Jumlah & 38 & 100 \\
\hline
\end{tabular}

Berdasarkan tabel 4 menunjukkan bahwa dari 38 reponden, hampir seluruhnya $(82 \%)$ penyembuhan luka perineum baik.

Untuk mengetahui hubungan antara pantang makanan dengan penyembuhan luka perineum di Ruang Mawar RSI Jemursari Surabaya menggunakan tabulasi silang dan didapatkan seperti tabel 5 
Tabel 5: Tabulasi silang pantang makanan dengan penyembuhan luka perineum di Poli Kandungan RSI Jemursari bulan Juni 2015

\begin{tabular}{|c|c|c|c|c|c|c|c|c|}
\hline \multirow{3}{*}{$\begin{array}{c}\text { Pantang } \\
\text { Makanan } \\
\text { atau } \\
\text { Tidak } \\
\text { Pantang } \\
\text { Makanan }\end{array}$} & & & \multicolumn{4}{|c|}{$\begin{array}{c}\text { Penyembuhan } \\
\text { Luka }\end{array}$} & \multicolumn{2}{|c|}{ Total } \\
\hline & \multicolumn{2}{|c|}{ Baik } & \multicolumn{2}{|c|}{ Sedang } & \multicolumn{2}{|c|}{ Buruk } & & \\
\hline & $\mathrm{N}$ & $\%$ & $\bar{N}$ & $\%$ & $\bar{N}$ & $\%$ & $\mathrm{~N}$ & $\%$ \\
\hline $\begin{array}{l}\text { Pantang } \\
\text { Makanan }\end{array}$ & 2 & 22 & 5 & 56 & 2 & 22 & 9 & 100 \\
\hline $\begin{array}{l}\text { Tidak } \\
\text { Pantang } \\
\text { Makanan }\end{array}$ & 29 & 100 & 0 & 0 & 0 & 10 & 29 & 100 \\
\hline Jumlah & 31 & 82 & 5 & 13 & 2 & 5 & 38 & 100 \\
\hline
\end{tabular}

Tabel 5 menunjukkan dari 9 responden yang melakukan pantang, terdapat 2 orang $(22 \%)$ penyembuhan luka perineumnya baik dan dari 29 responden yang tidak pantang makanan seluruhnya (100\%) penyembuhan lukanya baik. Hasil Uji Mann Whitney dengan tingkat signifikan $\alpha=0,05$. Setelah dilakukan uji didapatkan hasil $\rho=0,000$ artinya $\rho<\alpha$ maka $\mathrm{H}_{0}$ ditolak berarti ada hubungan pantang makanan dengan penyembuhan luka perineum di Ruang Mawar RSI Jemursari.

\section{PEMBAHASAN}

Berdasarkan tabel 3 menunjukkan bahwa dari 38 responden hampir seluruhnya $(76 \%)$ ibu tidan pantang makanan dan sebagian kecil (24\%) ibu tetap melakukan pantang makanan. Pantang makanan dilakukan karena adanya kepercayaan atau mitos dari kebudayaan sekitar. Sehingga sampai sekarang masih ada ibu nifas yang melakukan panyang makanan. Sedangkan ibu yang tidak melakukan pantang makanan hal ini karena ibu nifas tersebut sudah mampu untuk menolak tradisi atau pun kebudayaan disekitarnya. Hal ini sesuai dengan teori yang dikemukakan oleh Iskandar (2006) Tarak atau pantangan makanan adalah kebiasaan, budaya ataupun anjuran yang tidak diperbolehkan untuk mengkonsumsi jenis makanan tertentu misalnya sayuran, buah, ikan dan biasanya berkaitan dengan pemulihan kondisi fisik misalnya yang dapat mempengaruhi produksi ASI, ada pula makanan tertentu yang dilarang karena dianggap akan mengganggu penyembuhan luka jahitan pasca persalinan

Berdasarkan tabel 1 didapatkan bahwa $84 \%$ dari responden berusia 20-35 tahun Semakin tua usia ibu nifas, maka pengalaman dan informasi yang didapatkan semakin banyak. Sedangkan usia ibu yang masih muda cenderung mengikuti saran orang tua yang masih mengikuti budaya pantang makanan. Menurut seorang ahli psikologi perkembangan, Santrock (2011) yang dikutip dari Hanif Nifirman (2002), bahwa orang dewasa muda termasuk masa transisi, baik transisi secara fisik (physically trantition) transisi secara intelekual (cognitive trantition), serta transisi 
peran sosial (social role trantition). Pada masa ini adalah masa beralihnya pandangan egosentris menjadi sikap yang empati. Masa ini adalah masa yang penuh dengan masalah. Jika seseorang tidak siap untuk memasuki tahap ini, dia akan kesulitan dalam menyelesaikan tahap perkembangannya. Karena kondisi seperti inilah, sehingga ibu nifas yang berada pada kelompok umur 20-35 akan cenderung mengikuti budaya pantang makanan yang diajarkan oleh orang tua maupun lingkungan sekitar. Pada umur 20-35 tahun kondisi emosionalnya tidak terkendali, ia cenderung labil, resah, dan mudah memberontak, serta emosi seseorang sangat bergelora dan mudah tegang (Hanif Nofirman, 2011).

Berdasakan tabel 2 didapatkan bahwa $(87 \%)$ memiliki pendidikan terakhir Sekolah Menengah Atas (SMA). Semakin tingginya pendidikan ibu, maka ibu dapat berfikir secara rasional tentang pantang makanan yang benar selama masa nifas. Karena pendidikan merupakan jalur yang ditempuh untuk mendapatkan informasi. Jadi, apabila ibu nifas diberikan informasi tentang bahaya pantang makanan dengan jelas, benar dan komprehensif termasuk akibatnya maka ibu nifas tidak akan mudah terpengaruh atau mencoba melakukan pantang makanan. Menurut Notoatmodjo (2010) pendidikan berpengaruh terhadap pemahaman ibu tentang pantang makanan yang benar pada masa nifas. Pendidikan diperlukan untuk mendapatkan informasi misalnya hal-hal yang menunjang kesehatan sehingga dapat meningkatkan derajat hidup. Meskipun petugas kesehatan telah memberikan informasi yang jelas tentang pantang makanan yang benar pada masa nifas, tetapi mereka belum tentu paham. Mungkin saja mereka mengatakan sudah mengerti apa yang dikatakan petugas, namun sebenarnya belum mengerti. Ibu nifas yang sudah paham, tidak sekedar tahu apa jenis makanan yang perlu dipantang saat nifas atau bagaimana cara menyikapi pengaruh dari orang tua dan lingkungan sekitar tentang pantang makanan pada masa nifas., tapi juga mengapa pantang makanan yang salah itu harus dihindari oleh ibu nifas. Makin tinggi pendidikan seseorang, semakin mudah pula mereka menerima informasi, dan pada akhirnya makin banyak pula pengetahuan yang dimilikinya. Sebaliknya, jika seseorang tingkat pendidikannya rendah, akan menghambat perkembangan sikap seseorang terhadap penerimaan, informasi dan nilai - nilai yang baru diperkenalkan.

Tabel 4 menunjukan bahwa dari 38 responden (82\%) ibu nifas penyembuhan lukanya baik. Penyembuhan luka ini terjadi pada hari ke 6-7 pada masa nifas. Ciri-ciri penyembuhan luka yang baik yaitu, luka menutup, kering, tidak adanya pus sedangkan penyembuhan luka yang sedang yaitu basah, menutup dan tidak ada pus dan penyembuhan luka yang tidak baik yaitu basah, membuka dan terdapat pus. Hal ini sesuai dengan teori Mas'ada (2010) penyembuhan luka perineum adalah mulai membaiknya luka perineum dengan terbentuknya jaringan baru yang menutupi luka perineum dalam jangka watu 6-7 hari post partum. Kriteria penilaian luka adalah : 1) baik jika luka kering, perineum menutup dan tidak ada tanda infeksi (merah, bengkak, panas, nyeri, fungsioleosa), 2) sedang, jika luka basah, perineum menutup, tidak ada 
tanda-tanda infeksi (merah, bengkak, panas, nyeri, fungsioleosa), 3) buruk, jika luka basah, perineum menutup/membuka dan ada tanda tanda infeksi (merah bengkak, panas, nyeri, fungsioleosa).

Berdasarkan tabel 1

menunjukkan bahwa dari 38 responden hampir seluruhnya $(84 \%)$ ibu berusia 20-35 tahun. Semakin tua seseorang maka akan menurunkan kemampuan untuk penyatuan jaringan pada saat orang tersebut mengalami luka, dan semakin tua seseorang, maka semakin lama proses penyembuhan luka yang berlangsung. Hal ini sesuai dengan teori yang dikemukanan oleh Diaryasa (2010) yang dikutip dalam buku Ruth Jhonson (2007) bahwa penambahan usia berpengaruh terhadap semua penyembuhan luka sehubungan dengan adanya gangguan sirkulasi dan koagulasi, respon inflamasi yang lebih lambat dan penurunan aktifitas fibroblas. Kulit utuh pada orang dewasa muda yang sehat merupakan suatu barier yang baik terhadap trauma mekanis dan infeksi, begitu juga dengan efisiensi sistem imun, sistem kardiovaskuler, dan sistem respirasi, yang memungkinkan penyembuhan luka yang terjadi lebih cepat. Sistem tubuh yang berbeda "tumbuh" dengan kecepatan yang berbeda pula, tetapi lebih dari usia 35 tahun mulai terjadi penurunan yang signifikan dalam beberapa fungsinya, seperti penurunan efisiensi jantung, kapasitas vital, dan juga penurunan efesiensi sistem imun, yang masing masing masalah tersebut ikut mendukung terjadinya kelambatan luka seiring dengan penambahan usia.

Berdasarkan tabel 5 menunjukkan bahwa dari 38 responden terdapat 9 orang yang melakukan pantang makanan dan 2 orang diantaranya penyembuhan luka perineumnya baik, karena dalam hal ini meskipun ibu melakukan pantang makanan tertentu ibu nifas masih mengkonsumsi jenis makanan lain yang dibutuhkan dalam masa nifas. Dan sisanya berpantang makanan pada semua jenis makanan yang dibutuhkan ibu selama masa nifas. Sehingga dalam hal ini penyembuhan luka perineum ibu nifas buruk. Sedangkan 29 orang yang tidak melakukan pantang makanan seluruhnya penyembuhan luka perineumnya baik. Yaitu lukanya kering, menutup dan tidak ada tandatanda infeksi ( merah, bengkak, panas, nyeri dan fungsioleosa). Hasil penghitungan dianalisis menggunakan SPSS for Windows dengan Uji Mann Whitney dengan tingkat kemaknaan $\alpha$ $=0,05$. Hasil uji didapatkan $\rho=$ 0,000 , artinya $\rho<\alpha$ maka $\mathrm{H}_{0}$ ditolak berarti ada hubungan antara pantang makanan dengan penyembuhan luka perineum di Ruang Mawar RSI Jemursari Surabaya.

Penyembuhan luka perineum adalah proses pergantian dan perbaikan fungsi jaringan yang rusak. Menurut Smetzer (2002) salah satu faktor yang memepengaruhi penyembuhan luka perineum ialah pantang makanan. Tarak atau pantang makanan adalah kebiasaan, budaya ataupun anjuran yang tidak diperbolehkan untuk mengkonsumsi jenis makanan tertentu misalnya sayuran, buah, ikan dan biasanya berkaitan dengan pemulihan kondisi fisik misalnya yang dapat mempengaruhi produksi ASI, ada pula makanan tertentu yang dilarang karena dianggap akan mengganggu penyembuhan luka jahitan pasca persalinan.

Malnutrisi secara umum dapat mengakibatkan berkurangnya 
kekuatan luka, meningkatkan dehisensi luka, meningkatkan kerentanan terhadap infeksi, dan parut dengan kualitas yang buruk. Defisien nutrisi (sekresi insulin dapat dihambat, sehingga menyebabkan glukosa darah meningkat) tertentu dapat berpengaruh pada penyembuhan (Noyle, 2008).

\section{SIMPULAN}

1. Ibu post partum di wilayah RSI Jemursari Surabaya hampir seluruhnya tidak melakukan pantang makanan.

2. Ibu post partum di wilayah RSI Jemursari Surabaya hampir seluruhnya penyembuhan luka baik.

3. Ada hubungan antara pantang makanan dan penyembuhan luka perineum di RSI Jemursari Surabaya.

\section{DAFTAR PUSTAKA}

Ambarrawati (2008). Asuhan Kebidanan Nifas. Yogyakarta, Mitra Cendikia

Arisman (2009). Gizi dalam Daur Kehidupan, Edisi 2. Jakarta, EGC

Arikunto S (2010). Prosedur Penelitian Suatu

Pendekatan Praktek, Edisi V. Jakarta, Rineka Cipta

Christine, Henderson (2005). Buku Ajar Konsep Kebidanan. Jakarta, EGC

Cuningham, Gary (2006). Obstetri Williams. Jakarta, EGC

Dinkes Prov Jatim. (2010). Profil Dinas Kesehatan Provinsi Jawa Timur 2012. Jakarta, Dinas Kesehatan
Departemen Kesehatan RI (2002). Gizi Seimbang Menuju Hidup Sehat Bagi Ibu Hamil dan Menyusui. Jakarta, Dirjen Bina Kesehatan Masyarakat

Harnawatiadj (2008). Masa Nifas. http:// wordspress.com/ Diakses tanggal 16 April 2012

Herskovits, Melville J. (2007). Budaya. http:// www.coreindonesia.or.id. Diakses tanggal 16 April 2012

Krisnatuti, Diah (2004). Menu Sehat Untuk Ibu Hamil dan Menyusui. Bandung, Puspa Swara

Kartika (2008). Sehat Setalah Melahirkan. Klaten, Kawan Kita

Mochtar, rustman (2002). Sinopsis Obstetri, Jilid 1. Jakarta, EGC

Nofirman, Hanif (2011). Deawasa Muda. http:// www.Perubahandewasamu da.or.id Diakses tanggal 17 juli 2012

Notoadmodjo, Soekidjo (2002). Ilmu Kesehatan Masyarakat. Jakarta, Rineka Cipta

Notoadmodjo, Soekidjo (2010). Metodologi Penelitian Kesehatan. Jakartaa, Rineka Cipta

Notoadmodjo, Soekidjo (2003). Pendidikan dan Perilaku Kesehatan. Jakarta, Rineka Cipta

Nur Khasanah, Arifah (2011). Budaya Dan Mitos Seputar Kehamilan, kelahiran, Nifas, Menyusui, Dan Perawatan Anak. http:// arifahpratidinia.blogspot.co m/2011/04/budaya-dan- 
mitos-seputar-

kehamilan.html. Diakses

tanggal 17 Juli 2012

Nursalam (2003). Konsep dan Penerapan metodologi Penelitian Ilmu Keperawatan: Jakarta, Salemba Medika

Papalia (2007). Human Development. Jakarta, Salemba

Prawirohardjo, Sarwono (2008). Ilmu Kebidanan. Jakarta, Yayasan Bina Pustaka Sarwono Prawirohardjo

Saifuddin, Abdul Bari (2002). Buku Panduan Praktis

Pelayanan Kesehatan Maternal dan Neonatal. Jakarta

Subijakto (2011). Jenis Makanan yang Dipantang Pada
Masa Nifas. http:// subijakto25.blog.com.

Diakses tanggal 16 April 2012

Surinah (2008). Buku Pintar Kehamilan dan Persalinan. Jakarta, Gramedia Pustaka Utama

Sulistyawati, Ari (2009). Buku Ajar Asuhan Kebidanan pada Ibu Nifas. Yogyakarta, ANDI

Suparyanto (2010). Pantang Makanan Di Masa Nifas. http:// $\mathrm{dr}$ suparyanto.blogspot.com. Diakses tanggal 16 April 2012

Tengker, Freddy (2011). Asas-Asas dan Tatanan Hukum Adat. Bandung, Mandar Maju 